\title{
Changes in Metabolites of African Catfish (Clarias Gariepinus) Exposed to Different Salinity Levels
}

\author{
Alalibo, O.O. ${ }^{1}$, Gabriel, U.U ${ }^{2}$, Akinrotimi O.A ${ }^{3 *}$ \\ ${ }^{1,2}$ Department of Fisheries and Aquatic Environment, Faculty of Agriculture, Rivers State University, Nkpolu- \\ Oroworukwo, Port Harcourt, Nigeria \\ ${ }^{3}$ African Regional Aquaculture Center/ Nigerian Institute for Oceanography and Marine Research, P.M.B. \\ 5122, Port Harcourt, Nigeria
}

*Corresponding Author: Akinrotimi O.A, African Regional Aquaculture Center/ Nigerian Institute for Oceanography and Marine Research, P.M.B. 5122, Port Harcourt, Nigeria

\begin{abstract}
Changes in some blood biochemical parameters were studied in the juvenile and adult sizes of freshwater fish C.gariepinus under different saline exposure (0.00-control; 0.50; 1.00; 1.50; 2.00 and 2.50ppt) for a period of 15 days. The blood biochemical parameters evaluated werealbumin, total protein, lipids, total bilurubin, urea, creatinine and globulin. The results obtained indicated a significant $(P<0.05)$ reduction in the values of total protein, lipids, total bilurubin, creatinine and globulin. While the values of urea increased considerably in both sizes of the fish. However, albumins were within the same range in all concentrations of exposure. Thus it indicates that although fish survives and able to tolerate saline conditions. The variations of blood biochemical parameters can be considered as a kind of saline stress response particularly on metabolites.
\end{abstract}

Keywords: Salinity; Catfish, Metabolites; Stress; Blood chemistry

\section{INTRODUCTION}

Salinity refers to the degree of saltiness of a water body. It has been described as one of the important factors exerting selective effectson aquatic organisms. Salinity is defined as a measure of the amount of dissolved salts in the water [1]. Salinity is the correct chemical term for the sum concentration of all ionic constituents dissolved in inland waters, both fresh and saline. Habitat salinity represents a major abiotic factor that governs the activity and distribution of fishes and other aquatic animals. Furthermore, aquatic animals can either be stenohaline or euryhaline, which shows the level of osmotic tolerance of the organism. Stenohaline species such as the African catfish, can only withstand little ranges of salinity. While euryhaline species like the sea bass and some tilapias are able to tolerate a wide range of salinity, which enables them to move between freshwater and salt water and it is leading to many diverse adaptation strategies for different species to survive in different osmotic pressure regimes [2]. Because the autonomous osmoregulation in aquatic organisms is an energy demanding process, certain prevailing salinities might help to optimize growth or reproduction by decreasing osmoregulatory energy expenditure [3].The metabolic cost would be expected to be minimized during culture of fish in isotonic conditions, thus it can minimize the cannibalistic behavior of fishes, and indirectly improve the survival and growth performance of the African catfish [4].

The salinity stress caused by a change in the saltiness of the habitat, if not compensated for, interferes with the physiological homeostasis and routine biological processes of the organisms concerned. Most fishes are adapted to tolerate some degree of salinity stress (small for stenohaline and large for euryhaline species). The vast majority of species are restricted to habitats with relatively stable salinity [5]. By influencing the thermodynamic properties of water (e.g. density, heat capacity, solvent capacity for solids and gases, vapor pressure), salinity contributes greatly to defining habitat characteristics for fishes and other aquatic organisms. In addition, biochemical processes inside and outside cells are greatly influenced by salinity. The ionic strength of almost all environmental waters results virtually exclusively from dissolved inorganic ions, table salt $-\mathrm{NaCl}$ - in most cases [6]. 
The effects of stress resulting from handling during aquaculture operations on fish and methods of minimizing such effects have received considerable attention in recent years [7-9]. Stress induced by common practices such as handling, crowding, transport or poor water conditions can increase the incidence if diseases and mortality and salinity fluctuations undoubtedly impose stress on the physiology of the exposed fish population and can modify their structure, and is therefore an important factor affecting the outcome of any aquaculture venture. Stress disturbs the final internal balance, or homeostasis, and has further determinable effects on the performance of fish especially in the culture medium [10-11]. Fish has developed physiological and biochemical adaptations to cope with these constraints that minimize or eliminate the deleterious effects, which is called stress response. The evaluation of biochemical parameters has provided a tool for facilitating fish health management especially in the culture medium [12]. Blood chemistry parameters are used as indicators of physiological stress response in fish [13]. Saline stress response studies on the metabolites of fresh water fish C.gariepinus is limited, hence, the present study is undertaken to find out the saline stress response with emphasis on certain blood biochemical parameters.

\section{MATERials AND MethodS}

\subsection{Experimental Procedure}

A total of 120 C.gariepinus comprising 60 adult size (mean total length $31.88 \mathrm{~cm} \pm 3.56 \mathrm{SD}$; mean weight $988.42 \mathrm{~g} \pm 36.88 \mathrm{SD}$ ) and 60 juvenile size (mean length 15.99 \pm 6.01 ; mean weight 304.34 \pm 11.01 ) were procured from African Regional Aquaculture Centre (ARAC) Aluu, Port Harcourt, Rivers State, Nigeria. They were immediately taken to the hatchery where they were exposed to different levels of salinity: $0.00 \%$ (control); $0.50 \%$; $1.00 \%$; $1.50 \%$; $2.00 \%$ and $2.50 \%$ for a period of 15 days. The different levels of salinity concentrations used were achieved by dissolving $0.50,1.00,1.50,2.00$ and $2.50 \mathrm{~g}$ of common salt each in one liter of water to achieve the desired concentrations. The fish were stocked at the rate of 10 fish per tank in three replicates. They were fed with a commercial pelleted fish feed ( $40 \%$ crude protein) at $3 \%$ body weight twice daily.

\subsection{Sample Collection and Laboratory Analysis}

At the end of the experiment, blood sampling was conducted at the expiration of 15 days. Blood samples were collected from a total of 36 fish (six fish/treatment) with heparinized plastic syringe, fitted with 21 gauge hypodermic needle and preserved in lithium heparin bottles for analysis. The samples were centrifuged for 10 minutes at $3000 \mathrm{rpm}$. Then the resultant supernatant was transferred into sample bottles for analysis. The biochemical analysis was carried out using several analytical procedures. Lipids was analyzed based on the method previously described by Bucolo and David [14], totalbilurubin, albumin, urea and globulin concentration were estimated by the method previously described by Amundson and Zhou [15]. The total protein and creatinine concentrations were estimated by the method of Lowry et al. [16].

\subsection{Water Quality Analysis}

Physico-chemical characteristics of the water were monitored. Measurements of water parameters were taken on the first and the last day of the experimental period, Hydrogen ion concentration $(\mathrm{pH})$ was determined by the use of a $\mathrm{pH}$ meter (model HI 9812, Hannah Products, Portugal). Temperature was taken with mercury in glass thermometer. The salinity was measured using hand held refractometer (Model HRN - 2N, Adago Products, Japan). The values of dissolved oxygen, ammonia and nitrite were evaluated using the methods described by APHA [17]. The mortality of the fish during the experiment in the tank were taken and the percentage mortality calculated.

\subsection{Statistical Analysis}

Statistical analysis was carried out using SPSS software. The data was expressed as Mean \pm standard error and one-way analysis of variance was carried out at $\mathrm{P}<0.05$, and Tukey HSD Test was used for multiple comparisons.

\section{RESUlts}

The physicochemical parameters in aquaria water of C.gariepinus exposed to various concentrations of salinities are presented in Table 1 . The values of temperature, $\mathrm{pH}$, dissolved oxygen, ammonia and nitrite were within the same range in all concentrations of exposure. However, significant difference $(\mathrm{P}>0.05)$ was observed in the values of salinities. The metabolites in the plasma of C.gariepinus juveniles exposed to different salinity levels are presented in Table 2. The results indicated a significant reduction $(\mathrm{P}<0.05)$ comparable to the control in total bilurubin, creatinine, lipids, total 
protein and globulin while values for albumin were within the same range in all concentrations of exposure. However, a significant increase was observed in the values of urea. The same trend was equally observed in the adult sizes of the exposed C.gariepinus to different levels of salinity (Table 3). The comparative levels of total bilurubinin the fish exposed to different saline solutions are shown in Figure 1. Generally, total bilurubin decline with increasing concentration of the solution. The values of lipids were consistently higher in the adult fish than the juveniles. (Figure 1). Comparatively, the urea level in the exposed fish is shown in Figure 2. Higher values of urea were recorded in the juvenile, when compared to adult fish. Relative values of creatinine, albumin and globulin levels in the exposed fish were presented in Figures 3, 4, and 5 respectively. The values of creatinine and globulin reduced as the concentration of the saline solution increased. While albumin values were within the same range. Comparatively, the lipids and total protein level in the exposed fish is shown in Figure 6 and 7.Lower values of lipids and total protein were recorded in the juvenile, when compared to adult fish.

Table1. Physico - Chemical Parameters of Water in Exposure Tanks of C.gariepinus Exposed to Different Salinity levels

\begin{tabular}{|c|c|c|c|c|c|c|}
\hline \multicolumn{6}{|c|}{ Salinity Levels (ppt) } & \\
\hline Parameters & 0.00 & \begin{tabular}{|l|}
0.50 \\
\end{tabular} & 1.00 & 1.50 & 2.50 & 3.00 \\
\hline Temperature $\left({ }^{\circ} \mathrm{C}\right)$ & $29.62 \pm 4.11^{\mathrm{a}}$ & $28.62 \pm 3.22^{\circ}$ & $29.23 \pm 3.61^{\mathrm{a}}$ & $28.02 \pm 4.09^{\mathrm{a}}$ & $28.99 \pm 3.02^{\mathrm{a}}$ & $28.01 \pm 6.07^{\mathrm{a}}$ \\
\hline $\mathrm{pH}$ & $6.01 \pm 1.33^{\mathrm{a}}$ & $6.02 \pm 1.32^{\mathrm{a}}$ & $6.39 \pm 1.17^{\mathrm{a}}$ & $6.34 \pm 1.99^{\mathrm{a}}$ & $6.26 \pm 1.01^{\mathrm{a}}$ & $6.41 \pm 1.99^{\mathrm{a}}$ \\
\hline Ammonia $\left(\mathrm{mgL}^{-1}\right)$ & $0.30 \pm 0.01^{\mathrm{a}}$ & $0.38 \pm 0.03^{\mathrm{b}}$ & $1.02 \pm 0.02^{b}$ & $1.64 \pm 0.05^{\mathrm{b}}$ & $1.02 \pm 0.03^{\mathrm{b}}$ & $1.88 \pm 0.01^{\mathrm{b}}$ \\
\hline Dissolved Oxygen $\left(\mathrm{mgL}^{-1}\right)$ & $6.56 \pm 1.11^{\mathrm{b}}$ & $5.12 \pm 0.66^{\mathrm{b}}$ & $4.01 \pm 0.61^{\mathrm{ab}}$ & $3.56 \pm 1.01^{\mathrm{a}}$ & $3.41 \pm 0.91^{\mathrm{a}}$ & $3.02 \pm 1.02^{\mathrm{a}}$ \\
\hline Nitrite $\left(\mathrm{mgL}^{-1}\right)$ & $0.04 \pm 0.01^{\mathrm{a}}$ & $0.08 \pm 0.01^{\mathrm{b}}$ & $0.08 \pm 0.01^{\mathrm{b}}$ & $0.09 \pm 0.03^{\mathrm{c}}$ & $0.08 \pm 0.03^{\mathrm{c}}$ & $0.09 \pm 60.3^{c}$ \\
\hline Salinity (ppt) & $0.0 \pm 0.01^{\mathrm{a}}$ & $1.00 \pm 0.01^{\mathrm{b}}$ & $2.00 \pm 0.01^{\mathrm{c}}$ & $3.00 \pm 0.01^{\mathrm{d}}$ & $4.00 \pm 0.01^{\mathrm{e}}$ & $5.03 \pm 0.00^{f}$ \\
\hline
\end{tabular}

Mean within the same superscripts in the row are significantly different $(\mathrm{P}<0.05)$

Table2. Metabolites in the Plasma of C.gariepinus Juveniles Exposed to Different Salinity levels (Mean $\pm S D$ )

\begin{tabular}{|c|c|c|c|c|c|c|c|}
\hline & \multicolumn{7}{|c|}{ Metabolites (mmol/I) } \\
\cline { 2 - 8 } & Total Bilurubin & Urea & Creatine & Albumin & Globulin & Lipids & Total Protein \\
\hline $\mathbf{0 . 0 0}$ & $4.88 \pm 0.21^{\mathrm{a}}$ & $3.81 \pm 0.21^{\mathrm{a}}$ & $104.61 \pm 8.21^{\mathrm{c}}$ & $0.91 \pm 0.01^{\mathrm{a}}$ & $95.61 \pm 4.11^{\mathrm{a}}$ & $52.03 \pm 3.16^{\mathrm{d}}$ & $8.02 \pm 0.64^{\mathrm{c}}$ \\
\hline $\mathbf{0 . 5 0}$ & $2.93 \pm 0.61^{\mathrm{a}}$ & $5.02 \pm 0.71^{\mathrm{a}}$ & $90.21 \pm 7.21^{\mathrm{c}}$ & $0.92 \pm 0.01^{\mathrm{a}}$ & $82.61 \pm 7.11^{\mathrm{d}}$ & $48.11 \pm 2.14^{\mathrm{c}}$ & $6.01 \pm 0.24^{\mathrm{c}}$ \\
\hline $\mathbf{1 . 0 0}$ & $2.96 \pm 0.81^{\mathrm{a}}$ & $6.61 \pm 0.81^{\mathrm{b}}$ & $80.61 \pm 8.11^{\mathrm{b}}$ & $0.93 \pm 0.02^{\mathrm{a}}$ & $60.21 \pm 8.11^{\mathrm{c}}$ & $41.01 \pm 1.21^{\mathrm{b}}$ & $5.01 \pm 0.18^{\mathrm{b}}$ \\
\hline $\mathbf{1 . 5 0}$ & $2.95 \pm 0.84^{\mathrm{a}}$ & $7.41 \pm 0.21^{\mathrm{b}}$ & $60.71 \pm 6.21^{\mathrm{b}}$ & $0.90 \pm 0.01^{\mathrm{a}}$ & $37.61 \pm 2.11^{\mathrm{b}}$ & $39.03 \pm 2.11^{\mathrm{b}}$ & $4.08 \pm 0.27^{\mathrm{b}}$ \\
\hline $\mathbf{2 . 0 0}$ & $2.98 \pm 0.81^{\mathrm{a}}$ & $8.09 \pm 0.81^{\mathrm{b}}$ & $50.60 \pm 3.22^{\mathrm{a}}$ & $0.91 \pm 0.02^{\mathrm{a}}$ & $33.62 \pm 7.18^{\mathrm{b}}$ & $36.01 \pm 3.10^{\mathrm{b}}$ & $4.21 \pm 0.14^{\mathrm{b}}$ \\
\hline $\mathbf{2 . 5 0}$ & $1.96 \pm 0.72^{\mathrm{a}}$ & $9.81 \pm 0.21^{\mathrm{b}}$ & $25.02 \pm 2.11^{\mathrm{a}}$ & $0.94 \pm 0.03^{\mathrm{a}}$ & $25.71 \pm 2.14^{\mathrm{a}}$ & $31.01 \pm 2.14^{\mathrm{a}}$ & $3.01 \pm 1.11^{\mathrm{a}}$ \\
\hline
\end{tabular}

Means within the same column with different superscript are significantly different $(\mathrm{P}<0.05)$

Table3. Metabolites in the Plasma of C.gariepinusAdult Exposed to Different Salinity levels (Mean $\pm S D$ )

\begin{tabular}{|c|c|c|c|c|c|c|c|}
\hline \multirow[b]{2}{*}{$\begin{array}{c}\text { Salinity. } \\
\text { (ppt) }\end{array}$} & \multicolumn{7}{|c|}{ Metabolites (mmol/l) } \\
\hline & Total Bilurubin & Urea & Creatine & Albumin & Globulin & Lipids & Total Protein \\
\hline & & & & & $107.68 \pm 7.02^{\mathrm{e}}$ & 72.06 & \\
\hline & & $4.76 \pm($ & 7.72 & & $98.99 \pm 3.12^{\mathrm{d}}$ & 64.71 & \\
\hline & & $3.22 \pm 0.12^{\mathrm{b}}$ & $97.81 \pm 9.12^{b}$ & 1.97 & $85.02 \pm 5.88^{\mathrm{c}}$ & $53.61 \pm 0$. & \\
\hline & $5^{b}$ & $1.96 \pm 0.13^{2}$ & $87.38 \pm 2.16^{\mathrm{a}}$ & $1.98 \pm 0.12^{2}$ & $74.12 \pm 6.89^{b}$ & $44.71 \pm 1.21^{\mathrm{a}}$ & $6.06 \pm 0.21^{b}$ \\
\hline 2.0 & $3.90 \pm$ & $1.11 \pm 0.11^{2}$ & $67.46 \pm 2.31^{\mathrm{a}}$ & $1.93 \pm 0.11^{2}$ & $63.01 \pm 2.01^{b}$ & $40.66 \pm 1.08^{\mathrm{b}}$ & $5.71 \pm 0.14^{\mathrm{a}}$ \\
\hline 2.50 & $2.67 \pm 0.14^{\mathrm{a}}$ & $1.06 \pm 0.13^{\mathrm{a}}$ & $44.39 \pm 4.17^{\mathrm{a}}$ & $2.01 \pm 0.13^{\mathrm{b}}$ & $40.02 \pm 4.07^{\mathrm{a}}$ & $33.71 \pm 1.78^{\mathrm{a}}$ & $4.02 \pm 0.22^{\mathrm{a}}$ \\
\hline
\end{tabular}

Means within the same column with different superscript are significantly different $(\mathrm{P}<0.05)$

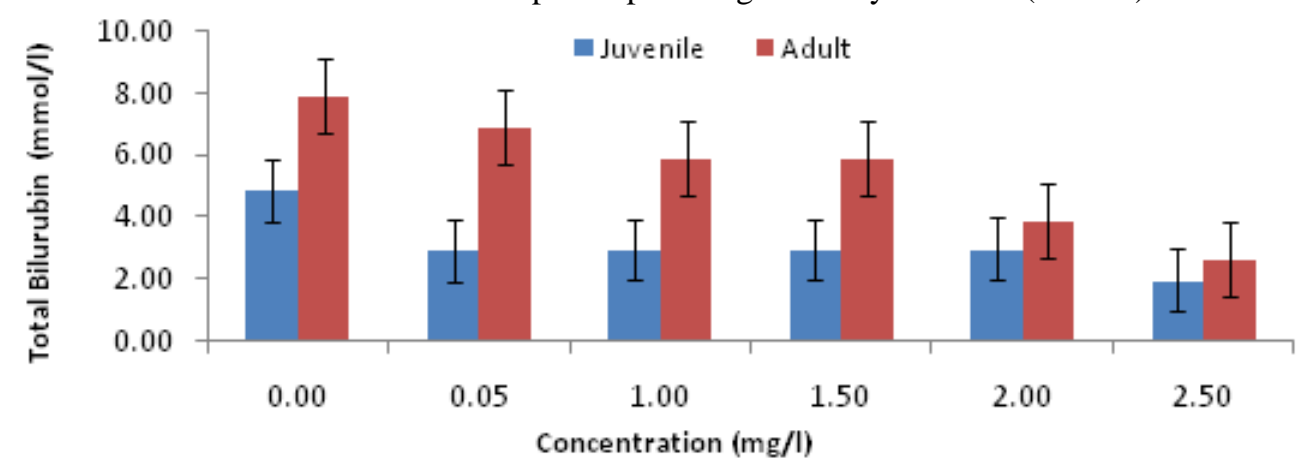

Figure1. Comparative values of Total Bilurubin in the Plasma of C.gariepinus Exposed to Different Salinity levels 


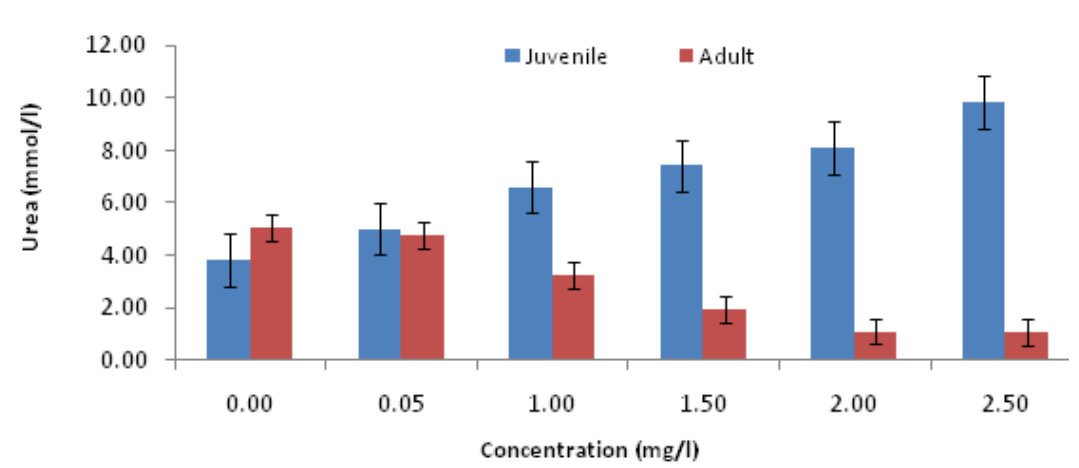

Figure2. Comparative values of Urea in the Plasma of C.gariepinus Exposed to Different Salinity levels

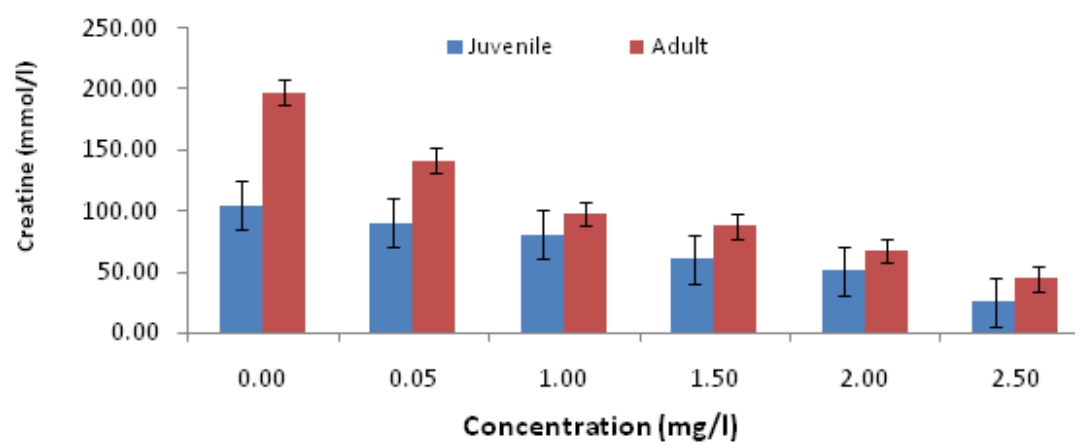

Figure3. Comparative values of Creatine in the Plasma of C.gariepinus Exposed to Different Salinity levels

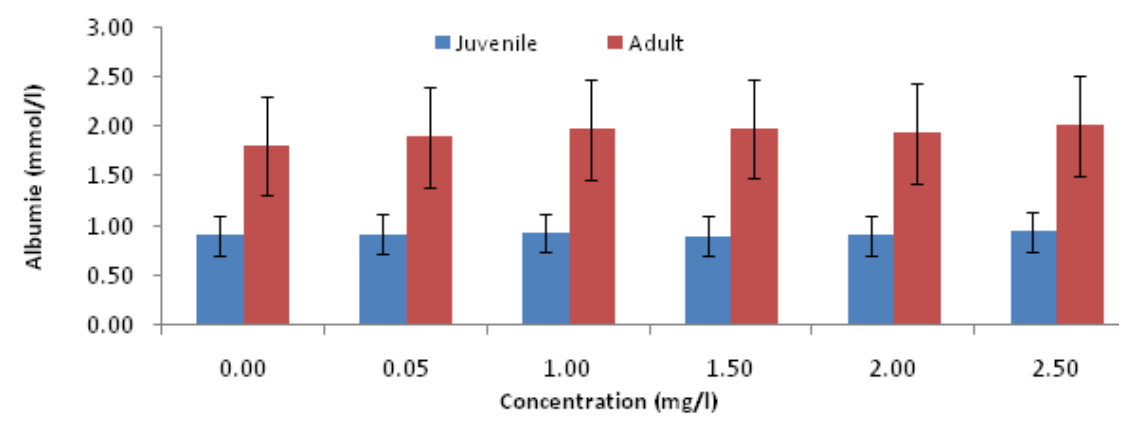

Figure4. Comparative values of Albumie in the Plasma of C.gariepinus Exposed to Different Salinity levels

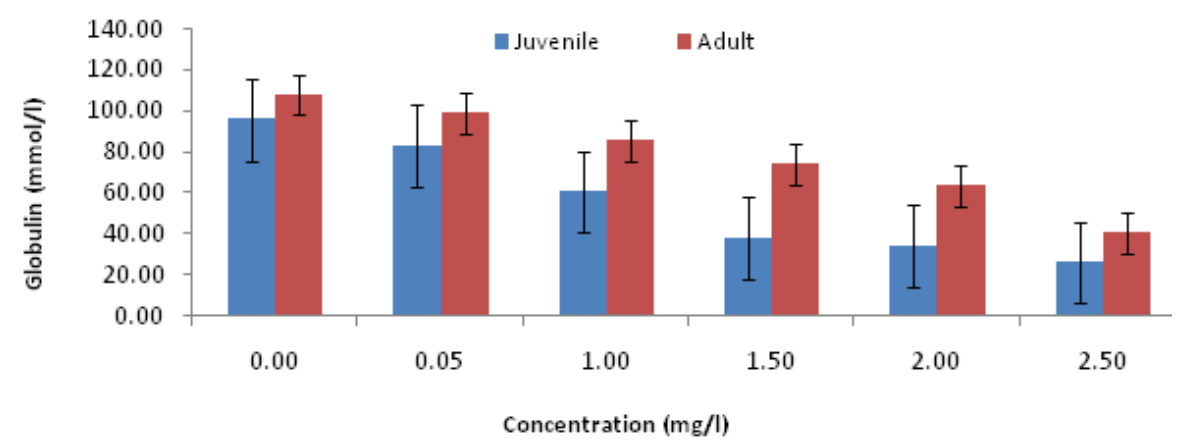

Figure5. Comparative values of Globulin in the Plasma of C.gariepinus Exposed to Different Salinity levels

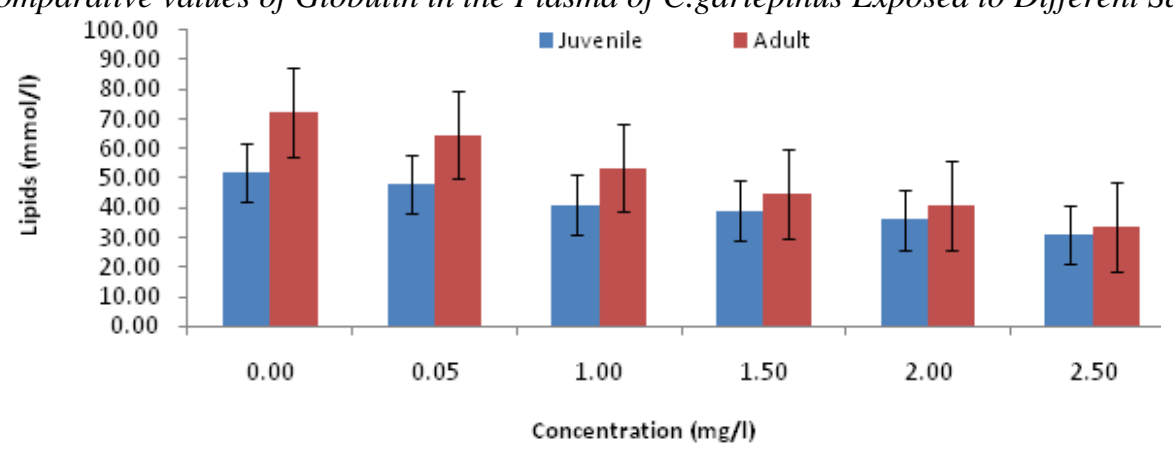

Figure6. Comparative values of Lipids in the Plasma of C.gariepinus Exposed to Different Salinity levels 


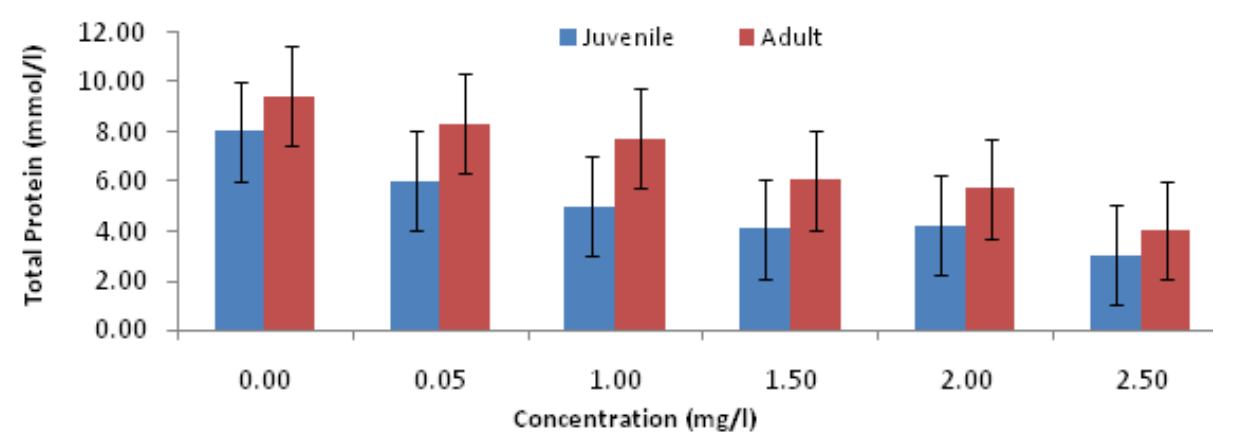

Figure7. Comparative values of Total Protein in the Plasma of C.gariepinus Exposed to Different Salinity levels

\section{DISCUSSION}

Generally, influence of water quality parameters could result to changes in the metabolites especially when the water is toxic. In this study the metabolites alteration and fluctuation is not connected to the water used in the experiment after the introduction of the saline solution. This is because there were no significant difference $(\mathrm{P}>0.05)$ between the control and the various concentration of the solution with regard to temperature, dissolved oxygen, $\mathrm{pH}$, ammonia and nitrite. The trend in the water quality parameters is similar to the result of previous authors on the exposure of fish to varying degrees of salinity [18].

The major responsibility of the blood or plasma is to transport absorbed metabolites and nutrient (organic and inorganic) through the body as well the transport of waste materials to various excretory organs where they can be eliminated from the body[19]. The presence of metabolites in the blood at high or low concentration is a very important clinical correlation. The values of total bilirubin and conjugated bilirubin reduced as the concentration of the saline solution increased. A decrease in plasma total bilirubin suggests liver cell damage [20]. Reduced values of bilirubin in this study indicate possible damage to the liver cells of $C$. gariepinus. A decrease in values of total bilirubin in the plasma could also be due to the inability of the liver to convert bilirubin into bile and urobilin, which phenomenon gives the urine in humans its yellow coloration [20].Plasma globulins and albumin, serve a vital function in carrying materials from one part of the fish to another via the circulation. They have nutritive, transporting, protective, buffering and energetic functions [21]. Globulin values reduced and albumin were within the same range as the concentration of saline solution increased. A similar result was also reported by Nte et al. [22] in exposure of Sarotherodon melanotheron to stress induced by industrial effluents the higher energy demand of the body to counter stress may trigger an alteration in these metabolites, a process in which both blood and structural protein are converted to energy during toxicant induced stress [23]. Urea and creatinine have been used as important indices for the evaluation of the effects of stress on the kidney using a variety of both in-vivo and in-vitro methods [24]. Creatinine in the experimental fish reduced during the exposure period, while the urea values increased as the concentration of the saline solution increased. The presence of increasing concentration of urea and reduced creatinine as opined by Calbreath [25] suggested the inability of the kidney to excrete these products, which further indicated a decrease in glomerular filtration rate.

The concentration of total protein is used as a basic index for the health status of fish [26] and it is an important non-specific immune parameter [27]. In the present study there was a reduction in the serum protein in the experimental fishes. Reduction in the values of total protein can be caused by structural liver alterations, reducing amino transferase activity and impaired control of fluid balance. This result corroborates the findings of Anyanwu et.al. [28] in exposure of Sarotherodon melanotheron to varying degrees of salinities. The decrease in protein content was probably due to reduced/perturbation of microsomal protein synthesis. The degradation of protein suggests the increase in proteolytic activity and possible utilization of their product for metabolic purpose [27]. The occasional decline in protein content could be due to decline in protein synthesis and increased proteolysis while an increase may be associated with increase in protein synthesis due to increase in enzyme activity involved in protein synthesis [27]. However authors have reported decline in protein content in fish exposed to stress. Lipids play a role in defensive and fat transport to the liver in the form of cholesterol ester for oxidation, granulation of cell division and acts as an antagonist to phospholipids, formation of bile acids and bile salts, 7-dehydrocholestrol and vitamin D3, 
corticosteroid hormone, androgens, estrogens and progesterone [29].Alteration in the cholesterol in the plasma of fish exposed to stress induced by salinity could be associated with toxicity stress which suppresses the activity of some enzymes responsible for lipid transformation thereby disrupting lipid metabolism [21].

However, in this study the values of total lipids reduced on exposure to saline medium and this may be because of increased in metabolic rate and demand for lipid accumulation. A lipid is a necessary compound of the structure of the cell membrane in fishes. This observation agrees with the findings of Gabriel and Akinrotimi [8], who reported that salinity, can impose stress on fresh water fish oxidative cells. According to them reduced concentrations of lipids in serum can be a result of damages to liver or kidney. It also indicates disorders of lipid and lipoprotein metabolism. Therefore low concentration of total lipids in the blood stream may suggest the dietary lipid imbalance [30].This lipid imbalance in C.gariepinus may be because of saline stress that leads to the imbalance of lipid metabolism.

\section{CONCLUSION}

The findings of this study have shown that different concentration of salinity significantly affects the metabolites of $C$. gariepinus which is more pronounced in the juvenile fish. This is accordance with previous studies that have reported alteration in internal function of fish organs, especially the liver when exposed to stress.

\section{REFERENCES}

[1] Kü ltz, D. \& Avila, K. (2001). Mitogen-activated protein kinases are in vivo transducers of osmosensory signals in fish gill cells. Comparative Biochemistry Physiology B Biochemistry and Molecular Biology, $129,821-829$.

[2] Bombata, F. H. A., and Busari, A. N. (2003). Influence of salinity on the developmental stages of African catfish, Heterobranchuslongifilis(Valenciennes, 1840). Aquaculture, 224, 213-222.

[3] Sampaio, L.A., and A.Bianchini. 2002. Salinity effects on Osmoregulation and Growth of the Euryhaline flounder Paralichthysorbigyanus. Journal of Experimental Marine Biology and Ecology, 269, 187-196.

[4] Kü ltz, D. and Avila, K. (2001). Mitogen-activated protein kinases are in vivo transducers of osmosensory signals in fish gill cells. Comp. Biochem. Physiol. B Biochem. Mol. Biol. 129, 821-829.

[5] Kü ltz, D. (2012). The combinatorial nature of osmosensing in fishes. Physiology (Bethesda), 27, 259-275.

[6] Kü ltz, D. (2013). Osmosis. In Fish Physiol, Vol. 32 (ed. S. McCormick, A. Farrell and C. Brauner), pp. 45-67. Oxford, UK: Elsevier.

[7] Evans, D.H. (1993). Osmotic and Ionic Regulation. In The Physiology of Fishes. CRC Press, USA. Fourie, J. J., 2006. A Practical investigation into Catfish (elarias gariepinus) farming in the Vaalharts Irrigation Scheme. Dissertation for Magistar Scientiae Faculty of Natural Agricultural Sciences, Department of Zoology and Entomology, University of the Free State.

[8] Gabriel, U.U., \& Akinrotimi, O.A. (2011). Management of Stress in fish for sustainable aquaculture development. Research, 3(4), $28-38$.

[9] Akinrotimi, O.A., Wilfred-Ekpripo, P. C, \& Ukwe, O.I.K (2018). Oxidative Stress in Tilapia guineensis Exposed to Paraquat Dichloride in the Laboratory. Journal of Advanced Research in Medical \& Pharmaceutical Sciences, 3(5), 14-18.

[10] Foss,A., Evensen, T.H., Imsland A.K., \& Oeistad, V. (2001). Effects of reduced salinities on growth, food conversion efficiency and osmoregulatory status in the spotted wolfish. Journal of Fish Biology, 59, 416420.

[11] Imsland,A.B., Gunnarson, S., Foss, A., Stefansson. S.D. (2002). Gill Na+, K+-ATPase activity, plasma chloride and osmolalilty in juvenile turbot (Scophthalmus maximus) reared at different temperatures and salinities. Aquaculture, 39, 1-13.

[12] Nte, M.E., Edun, O.M and Akinrotimi O.A. (2018).Biochemical Changes in Mudskipper (Periophthalmus papilio) exposed to sodium bromide. International Journal of Advanced Research in Medical \& Pharmaceutical Sciences 3(2):1-6.

[13] George, A.D.I., Akinrotimi O.A.,\& Nwokoma,U. K. (2017).Haematological Changes in African Catfish (Clarias gariepinus) Exposed To Atrazine and Metolachlor in the Laboratory. Journal of Fisheries Science.com. 11 (3), 48-54.

[14] Amundson, D.M., \& Zhou, M. (1999). Fluorometric method for the enzymatic determination of cholesterol. Journal of Biochemistry and Biophysical. Methods, 38, 43-52.

[15] Lowry, O.H, Rosenbrough, N.J, \& Farr A.L, Randall, R.J. (1951).Protein measurement with folin phenol reagent. Journal of Biology and Chemistry, 193, 265-270. 
[16] APHA, (1989). American water works association and water pollution control, 1980.Standard methods for the examinations of water and west water, 15th edn. American, Public,Health Association, Washington DC. 1134.

[17] Gabriel, U.U., Anyanwu, P.E., \& Akinrotimi O. A. (2007). Effect of Freshwater Challenge on the Blood Characteristics of Sarotherodon melanotheron. Agricultural Journal, 2(3), 388-391.

[18] Nte, M.D., Hart, A.I., Edun, O.M., \& Akinrotimi, O.A. (2011a). Effect of industrial effluent on haematological parameters of Black jaw tilapia Sarotherodon melanotheron. Continental Journal of Environmental Science, 5(2), 29-37.

[19] Cheesborough, M. (1992), Medical laboratory manual for tropical countries. Bultlework.Cambridge press. Pp $472-505$.

[20] Ganeshwade R.M. (2012). Effect of Dimethoate on the level of cholesterol in freshwater Puntiu sticto(Ham). Science Research Reporter, 2(1), 26-29.

[21] Nte, M.D., Hart, A.I., Edun, O.M., \&Akinrotimi, O.A. (2011b). Alterations in enzymes activities as a biomarker in blackjaw tilapia (Sarotherodon melanotehron) exposed to industrial effluents. Continental Journal of Biological Science,4(2),37-44.

[22] Das, P. C., Ayappan S., Das, B. K. and Jenas, J. K. (2004). Nitrite toxicity inn Indian major carps sublethal effect on selected enzymes in fingerlings of Labiorohita and Cirrhinos mrigala. Comparative Biochemistry and Physiology, 138,13-18.

[23] Davis, M. E. and Bernat, W. O. (1994). Renal methods for toxicology, in Hayes. Harvard pub. Pp 871 894.

[24] Calbreath, C. A. (1992). Clinical Biochemistry. Cambridge press. Pp 50-56.

[25] Akinrotimi O.A., Edun, O.M, and Ukwe,O.I.K (2018).Effects of Anaesthetics on Metabolic Enzyme Activities in African Catfish, Clarias gariepinus (Burchell, 1822) Journal of FisheriesSciences.com 12(1): 022-028.

[26] Magar, R.S., \& Shaikh A. (2012). Biochemical changes in proteins and amino acids in Channa punctatusin responses to sub lethal treatment with the insecticide malathion. Trend Life Sciiences, 1(3), 19-25.

[27] Anyanwu, P.E., Gabriel U.U., Anyanwu, A.O. \& Akinrotimi, O. A. (2007). Effect of salinity Changes on Haematological Parameters of Sarotherodon melanotheron from Buguma Creek Niger Delta. Journal of Animal Veterinary Advances, 6(5), 658 - 662.

[28] Sujatha K, Joice A.A, and Senthilkumaar P (2013). Total protein and lipid content in edible tissues of fishesfrom Kasimodu fish landing centre, Chennai, Tamilnadu. Eur.J. Exp.Biol., 3(5):252-257.

[29] Tak A.M, Bhat, F.A, Jan U, \& Shah G.M. (2014). Changes in Carbohydrate Metabolism in Cyprinu scarpioVar. during Short Term Exposure to Dimethoate. Research Journal of Pharmaceutical, Biology and Chemical Sciences, 5(2), 1466-147.

Citation: Akinrotimi O.A, et.al, "Changes in Metabolites of African Catfish (Clarias Gariepinus) Exposed to Different Salinity Levels”. International Journal of Innovative Studies in Aquatic Biology and Fisheries, 5(4), pp.1-7.http://dx.doi.org/10.20431/2454-7670.0504001

Copyright: (C) 2019 Authors. This is an open-access article distributed under the terms of the Creative Commons Attribution License, which permits unrestricted use, distribution, and reproduction in any medium, provided the original author and source are credited. 